\title{
Effect of clotrimazole on Naegleria fowleri
}

\author{
ADELE JAMIESON \\ From the Amoebic Research Unit, Institute of Medical and Veterinary Science, Adelaide, South Australia
}

SYNOPSIS The sensitivity of 18 strains of Naegleria fowleri to clotrimazole (Bay b5097) was tested. They showed minimal inhibitory concentrations in the range $0 \cdot 03-0 \cdot 125 \mu \mathrm{g} / \mathrm{ml}$, and minimal amoebicidal concentrations in the range $0 \cdot 125-0 \cdot 25 \mu \mathrm{g} / \mathrm{ml}$. Mice inoculated with $N$. fowleri were not protected from infection by doses of $100 \mathrm{mg}$ clotrimazole $/ \mathrm{kg}$ per day given for five days after inoculation. Mice had serum levels of up to $6 \mu \mathrm{g} / \mathrm{ml}$ in the first 32 hours after inoculation. Therefore clotrimazole appears to be ineffective in protecting against infection with $N$. fowleri.

Few drugs have in vitro activity against Naegleria fowleri, the amoebo-flagellate which causes primary amoebic meningo-encephalitis in man. Carter (1969) showed that amphotericin B immobilized $N$. fowleri at a concentration of $0.6 \mu \mathrm{g} / \mathrm{ml}$ and inhibited growth at $0.075 \mu \mathrm{g} / \mathrm{ml}$. Mice inoculated intranasally with $N$. fowleri were protected from infection by intraperitoneal doses of $7.5 \mathrm{mg} / \mathrm{kg}$ per day of amphotericin $B$. This drug has been used to treat successfully at least one patient with primary amoebic meningoencephalitis (Anderson and Jamieson, 1972a). However, amphotericin B is nephrotoxic in $80 \%$ of patients (Goodman and Gilman, 1970).

Amphotericin B is primarily an antifungal agent. Clotrimazole (Bay b5097), already known to have antifungal and trichomonacidal activity (Woutters, 1971; Weuta, 1972), has shown very promising amoebicidal activity in vitro (Jamieson and Anderson, 1974). In vitro studies of clotrimazole have been extended, and the effectiveness of this drug in protecting mice from infection with $N$. fowleri has been evaluated.

\section{Material and Methods}

\section{IN VITRO STUDIES}

A stock $0 \cdot 1 \%$ solution of clotrimazole, which is poorly soluble in water, was prepared with dimethylsulphoxide.

This was diluted with water and Chandler Fulton 'A' (CFA), the medium for axenic growth (Anderson and Jamieson, 1972b), to give a concentration of $10 \mu \mathrm{g}$ clotrimazole/ml. All further dilutions were

Received for publication 22 December 1974.

\begin{tabular}{|c|c|c|}
\hline Strain & Source & Country \\
\hline $\begin{array}{l}\text { NHI } \\
\text { Morgan } \\
\text { Northcott } \\
\text { McMahon } \\
\text { Oram } \\
\text { Vitek } \\
\text { 0359 } \\
0360 \\
\text { Q838 } \\
\text { HB-1 } \\
\text { MW4U } \\
\text { PA14 } \\
\text { PA34 } \\
\text { PA90 } \\
\text { PA105 } \\
\text { PA117 } \\
\text { K1 } \\
\text { K71 }\end{array}$ & 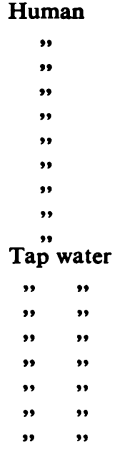 & $\begin{array}{c}\text { New Zealand } \\
\text { Australia } \\
\quad " \\
\text { " } \\
\text { Czechoslovakia } \\
\text { Belgium } \\
\text { " } \\
\text { USA } \\
\text { Australia } \\
\text { " } \\
\text { " } \\
" \\
" \\
" \\
"\end{array}$ \\
\hline
\end{tabular}

Table I Sources of strains of Naegleria fowleri

made with CFA. The sources of strains used are shown in table $\mathrm{I}$.

Studies of the survival of 18 strains of $N$. fowleri in CFA containing clotrimazole were done as follows: $100 \mathrm{~mm}^{3}$ of a culture containing a known concentration of trophozoites was inoculated into tubes with $1 \mathrm{ml}$ of the CFA-clotrimazole in doubling dilutions. The tubes were incubated at $37^{\circ} \mathrm{C}$ for five days. Then motile cells were counted using a Spencer bright-line haemocytometer. A control of CFA without clotrimazole, inoculated as above, was used. A control of CFA with dimethylsulphoxide was not included because $N$. fowleri is able to grow in the presence of $0.7 \%$ of this substance (unpublished observation). The highest concentration of clotrimazole in CFA used was $10 \mu \mathrm{g} / \mathrm{ml}$; this contained only $0.01 \%$ dimethylsulphoxide. 
IN VIVO STUDIES

\section{Mouse Protection}

Mice were dosed orally with a suspension of clotrimazole in $1 \%$ methyl cellulose mucilage. (Some mice died with very severe distension of the gastrointestinal tract in a trial study using a solution of clotrimazole in polyethylene glycol 400 .)

The dose used was $100 \mathrm{mg} / \mathrm{kg}$ per day with mice weighing approximately $15 \mathrm{~g} ; 0.75 \mathrm{mg}$ clotrimazole in $0.25 \mathrm{ml}$ methyl cellulose was given morning and evening with an oral dosing needle.

Three groups of mice were used: 10 uninfected and 10 infected control mice were given methyl cellulose, and 10 infected test mice were given clotrimazole in methyl cellulose.

Under light ether anaesthesia the mice were infected by intranasal inoculation of $50 \mathrm{~mm}^{3}$ of a culture of strain Q1230 containing 1600 trophozoites/ $\mathrm{mm}^{3}$. Clotrimazole treatment was started immediately after inoculation and continued twice daily for five days. The mice were fed and watered ad libitum and observed for 16 days thereafter. After this time the remaining infected mice were killed and their brains were removed and bisected. One half brain and a portion of liver were cultured, and the other was examined histologically along with liver, kidney, spleen, and suprarenal tissue.

\section{Bioassay of Clotrimazole Levels in Mouse Serum}

A stock $1 \%$ solution of clotrimazole in chloroform was prepared and stored in the dark at $4^{\circ} \mathrm{C}$. It was diluted with a $0.01 \mathrm{M}$ phosphate buffer $(\mathrm{pH} \mathrm{7.2)}$ to give standard solutions containing $0.02,0.1,0.5,2$, and $10 \mu \mathrm{g}$ clotrimazole $/ \mathrm{ml}$. Candida pseudotropicalis was used as the test organism because it required a minimal inhibitory concentration (MIC) of below $0.01 \mu \mathrm{g} / \mathrm{ml}$ (Holt and Newman, 1972). Assay plates were prepared using Sabouraud agar (pH 7·2). A 10 $\mathrm{ml}$ base layer in a $9 \mathrm{~cm}$ Petri dish was covered with a $4 \mathrm{ml}$ seed layer containing $0.02 \mathrm{ml}$ of an overnight culture of $C$. pseudotropicalis in Sabouraud broth without cycloheximide.

Eighty-five mice were used: 17 controls received methyl cellulose alone and 68 received clotrimazole in methyl cellulose. The dose was $0.25 \mathrm{ml}$ containing $0.75 \mathrm{mg}$ clotrimazole (as used in the protection study). The first dose was given at $9 \mathrm{am}$. Four mice receiving clotrimazole and one control mouse were killed hourly for 8 hours, when the next dose was given to the remainder. Five mice were killed at 9 am the following day, the third dose was given to the remainder, and then five mice were killed hourly for the next 8 hours.

Blood was obtained by cardiac puncture under ether anaesthesia, and the serum was used to deter- mine the degree of inhibition of $C$.pseudotropicalis in the assay plates.

Antibiotic assay discs (Whatman AA, $13 \mathrm{~mm}$ ) were used; one (test) soaked with $0.1 \mathrm{ml}$ serum and one (standard) soaked with $0.1 \mathrm{ml}$ of $10 \mu \mathrm{g} / \mathrm{ml}$ solution of clotrimazole were used on each plate. The plates were incubated overnight at $37^{\circ} \mathrm{C}$, and the zones of inhibition were measured with calipers fitted with a Vernier scale.

Ten sets of standard plates using the same batch of agar as in the test plates were set up with two discs per plate. As well as the five standard solutions, a control of phosphate buffer alone was used. These plates were incubated and measured as described above.

\section{Results}

\section{IN VITRO STUDIES}

The susceptibility of 18 strains of $N$. fowleri to clotrimazole is shown in table II. The MIC ranged from 0.03 to $0.215 \mu \mathrm{g} / \mathrm{ml}$ and the minimal amoebicidal concentrations (MAC) from 0.125 to $0.25 \mu \mathrm{g} / \mathrm{ml}$.

The effect of the size of the inocula (which ranged

\begin{tabular}{|c|c|c|c|}
\hline Strain & Inoculum $^{1}$ & $M I C(\mu g / m l)$ & $M A C(\mu \mathrm{g} / \mathrm{ml})$ \\
\hline NHI & 1700 & $0 \cdot 125$ & 0.25 \\
\hline " & 1380 & - & 0.15 \\
\hline & 260 & 0.06 & 0.125 \\
\hline Morgan & 870 & 0.03 & $0 \cdot 125$ \\
\hline$"$ & 390 & - & 0.15 \\
\hline & 365 & - & 0.15 \\
\hline Vitek & 560 & 0.06 & $0 \cdot 125$ \\
\hline$"$ & 370 & - & $0 \cdot 15$ \\
\hline & 300 & - & $0 \cdot 15$ \\
\hline McMahon & 740 & 0.06 & 0.125 \\
\hline $0260 "$ & 440 & 一 & $0 \cdot 15$ \\
\hline 0360 & 310 & - & $0 \cdot 15$ \\
\hline & 300 & 0.06 & 0.25 \\
\hline Northcott & 1000 & 0.06 & 0.25 \\
\hline & 375 & - & 0.15 \\
\hline HB-1 & 310 & 0.06 & 0.125 \\
\hline & 185 & - & 0.15 \\
\hline Oram & 790 & $0 \cdot 125$ & 0.25 \\
\hline & 355 & - & $0 \cdot 15$ \\
\hline 0359 & 600 & 0.06 & 0.25 \\
\hline & 410 & - & 0.15 \\
\hline MW4U & 225 & - & $0 \cdot 15$ \\
\hline PA105 & 550 & 0.06 & 0.25 \\
\hline & 240 & - & 0.15 \\
\hline PA90 & 420 & 0.125 & 0.25 \\
\hline & 270 & - & $0 \cdot 15$ \\
\hline K71 & 1050 & - & $0 \cdot 15$ \\
\hline & 260 & - & 0.15 \\
\hline PA117 & 720 & 0.06 & 0.25 \\
\hline & 300 & - & 0.15 \\
\hline PA34 & 650 & 0.06 & 0.25 \\
\hline - & 350 & - & $0 \cdot 15$ \\
\hline PA14 & 420 & 0.125 & 0.25 \\
\hline & 410 & - & $0 \cdot 15$ \\
\hline Q838 & 830 & 0.125 & 0.25 \\
\hline
\end{tabular}

Table II In vitro susceptibility of 18 strains of Naegleria fowleri to clotrimazole

${ }^{1}$ Inoculum $=$ no. of trophozoites $/ \mathrm{mm}^{2}$ 


\begin{tabular}{lcll}
\hline Inoculum & No. of Strains & $M I C(\mu \mathrm{g} / \mathrm{ml})$ & $M A C(\mu \mathrm{g} / \mathrm{ml})$ \\
\hline $185-250$ & 2 & - & $0 \cdot 15$ \\
$251-350$ & 9 & 0.06 & $0 \cdot 16$ \\
& & & $(0 \cdot 125-0 \cdot 25)$ \\
$351-450$ & 10 & $0 \cdot 125$ & $0 \cdot 17$ \\
& & $0 \cdot 15-0 \cdot 25)$ \\
$451-550$ & 1 & 0.06 & $0 \cdot 25$ \\
$551-650$ & 3 & $0 \cdot 06$ & $0 \cdot 21$ \\
& & & $(0 \cdot 125-0 \cdot 25)$ \\
$651-750$ & 2 & 0.06 & $0 \cdot 19$ \\
$751-850$ & 2 & $0 \cdot 125$ & $(0 \cdot 125-0 \cdot 25)$ \\
$851-950$ & 1 & $0 \cdot 03$ & $0 \cdot 25$ \\
$950-1050$ & 2 & $0 \cdot 06$ & $0 \cdot 125$ \\
1400 & 1 & & $(0 \cdot 15-0 \cdot 25)$ \\
1700 & 1 & - & $0 \cdot 15$ \\
& & $0 \cdot 125$ & $0 \cdot 25$ \\
\hline
\end{tabular}

Table III Effect of inoculum size on in vitro susceptibility of Naegleria fowleri to clotrimazole

Inoculum $=$ no. of trophozoites $/ \mathrm{mm}^{3}$

Values in parentheses represent ranges

from 185 to 1700 trophozoites $/ \mathrm{mm}^{3}$ ) on the $\mathrm{MIC}$ and MAC is shown in table III. The number of times each strain was tested at different inoculum sizes is too small to show any reliable trend.

\section{IN VIVO STUDIES}

\section{Mouse Protection}

All the uninfected controls receiving methyl cellulose survived. The results for the infected mice are shown in table IV. Twenty-one days after infection there were three mice left in the treated, and two in the untreated group. These mice were killed and their brains were removed and bisected. One-half of the brain and a portion of liver were cultured; the other half was examined histologically. The results of culture are shown in table V. Only the mouse with the positive brain culture had amoebae in the histological sections.

Bioassay of Clotrimazole Levels in Mouse Serum The zone diameters from the 10 sets of standard plates were averaged to give a standard curve from

\begin{tabular}{|c|c|c|c|c|}
\hline \multirow{2}{*}{ Day } & \multicolumn{2}{|l|}{ Deaths } & \multicolumn{2}{|l|}{ Deaths } \\
\hline & Methyl Cellulose & Culture & $\begin{array}{l}\text { Clotrimazolel } \\
\text { Methyl Cellulose }\end{array}$ & Culture $^{1}$ \\
\hline 5 & 2 & $\perp$ & 2 & + \\
\hline 6 & 5 & + & 3 & + \\
\hline 15 & 1 & + & 1 & + \\
\hline 17 & & & 1 & + \\
\hline
\end{tabular}

Table IV In vivo activity of clotrimazole in mice infected with Naegleria fowleri

$1+$ - Amoebae grown from suspension of mouse brain in water

\begin{tabular}{|c|c|c|c|}
\hline \multicolumn{2}{|c|}{ Methyl Cellulose } & \multicolumn{2}{|c|}{ Clotrimazole/Methyl Cellulose } \\
\hline Brain & Liver & Brain & Liver \\
\hline- & - & - & - \\
\hline \pm & $=$ & & \\
\hline
\end{tabular}

Table V Culture of brain and liver of mice infected with Naegleria fowleri

which the serum level corresponding to a given zone diameter could be read. The standard disc on each test plate was used to locate a curve, parallel to the standard, which gave the serum level. The results from the four test mice killed each hour were averaged and are presented in the figure.

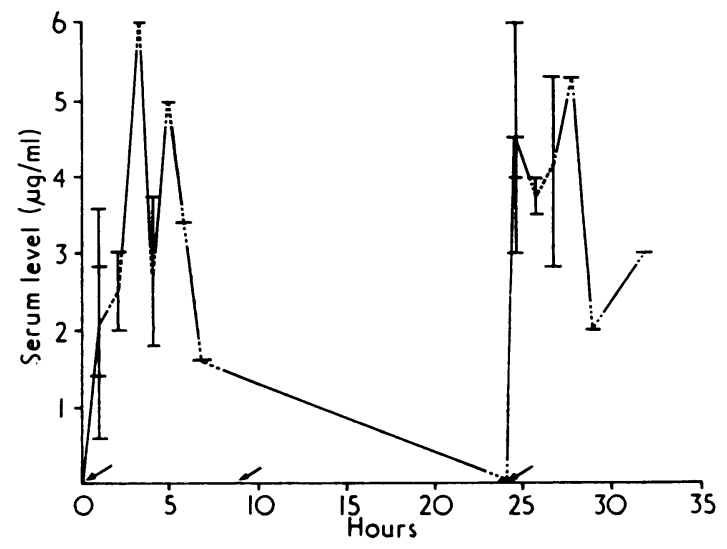

Figure Serum levels of clotrimazole in mice. $\measuredangle=$ dose of $50 \mathrm{mg}$ clotrimazole $/ \mathrm{kg}$ given; - serum level for each mouse; - mean of levels. Where less than four values are shown, insufficient serum was obtained from some of the mice; the graph is drawn with dotted lines to indicate this.

\section{Discussion}

The in vitro studies showed that the MIC of clotrimazole for various strains of $N$. fowleri ranged from 0.03 to $0.125 \mu \mathrm{g} / \mathrm{ml}$ and the MAC from 0.125 to $0.25 \mu \mathrm{g} / \mathrm{ml}$. These concentrations should be attainable therapeutically, although actual cerebrospinal fluid and brain levels in humans are not known.

Plempel et al (1969) successfully treated Candida albicans meningitis in mice with doses twice daily of $50 \mathrm{mg} / \mathrm{kg}$ clotrimazole for five days after infection. Mice were not protected from infection by $N$. 
fowleri with the same regimen. The serum levels achieved in mice in the first $\mathbf{3 2}$ hours after infection should have been sufficiently high to inhibit amoebic multiplication. A level of $6 \mu \mathrm{g} / \mathrm{ml} 3$ hours after a single dose of $50 \mathrm{mg} / \mathrm{kg}$ is comparable with a level of $7 \mu \mathrm{g} / \mathrm{ml} 4$ hours after a dose of $100 \mathrm{mg} / \mathrm{kg}$ (Plempel et al, 1969). In the well vascularized region of the nasal mucosa, where the amoebae are found in the first three days after inoculation (Carter, 1970), there would be ample exposure of the amoebae to bloodcontaining amoebicidal levels of clotrimazole.

Plempel and Bartmann (1972) showed that an effective level of clotrimazole in the blood from the fourth to the fifth days following infection cannot be achieved. This is because clotrimazole causes the induction or activation of the liver enzymes which catabolize it. In this paper it has been shown that adequate serum levels were achieved in mice during the first 32 hours of treatment. As pointed out, this is the period when the amoebae should be especially vulnerable.

Thus, although clotrimazole is very promising in its in vitro activity against $N$. fowleri, its efficacy in treating infections (even when given within minutes of inoculation) is negligible. In the clinical sphere, a patient would be unlikely to receive treatment until at least 72 hours after infection, by which time the amoebae would have begun to invade the meninges and brain (Carter, 1970).

In view of these results, clotrimazole cannot replace amphotericin B as the drug of choice in the treatment of primary amoebic meningo-encephalitis caused by $N$. fowleri.

I wish to thank Miss J. Rust for her assistance with the animal trials and Bayer Australia for providing samples of clotrimazole.

\section{References}

Anderson, K. and Jamieson, A. (1972a). Primary amoebic meningo-encephalitis. (Letter). Lancet, $2,379$.

Anderson, K. and Jamieson, A. (1972b). Agglutination test for the investigation of the genus Naegleria. Pathology, 4, 273-278.

Carter, R. F. (1969). Sensitivity to amphotericin B of a Naegleria sp. isolated from a case of primary amoebic meningoencephalitis. J. clin. Path., 22, 470-474.

Carter, R. F. (1970). Description of a Naegleria sp. isolated from two cases of primary amoebic meningo-encephalitis, and of the experimental and pathological changes induced by it. J. Path. 100, 217-244.

Goodman, L. S. and Gilman, A. (1970). The Pharmacological Basis of Therapeutics, 4th edition, p. 1301. Macmillan, New York.

Holt, R. J. and Newman, R. L. (1972). Laboratory assessment of the antimycotic drug clotrimazole. J. clin. Path., 25, 1089-1097.

Jamieson, A. and Anderson, K. (1974). Primary amoebic meningoencephalitis. (Letter). Lancet, 1, 261.

Plempel, M. and Bartmann, K. (1972). New experimental data on the oral antimycotic clotrimazole. In Advances in Antimicrobial and Antineoplastic Chemotherapy: Proceedings of the VIIth International Congress of Chemotherapy, Prague, 1971, edited by M. Hejzlar, M. Semonsky, and S. Masák, pp. 949-951. Avicenum, Prague.

Plempel, M., Bartmann, K., Büchel, K. H., and Regel, E. (1969). Experimentelle Befunde über ein neues, oral wirksames Antimykotikum mit breitem Wirkungsspektrum. Dtsch. med. Wschr., 94, 1356-1364.

Weuta, H. (1972). Clotrimazole vaginal tablets-clinical investigation in an open study. Drugs made in Germany, 15, 121-126.

Woutters, A. (1971). Comparison of activity of various trichomonacides in vitro. In International Symposium on Diagnosis and Chemotherapy of Urinary and Genital Infections due to Protozoa, Fungi and Bacteria, Florence, May 1971. 